\title{
Suppression of Cerulein-Induced Cytokine Expression by Antioxidants in Pancreatic Acinar Cells
}

\author{
Ji Hoon Yu, Joo Weon Lim, Wan Namkung, Hyeyoung Kim, and Kyung Hwan Kim \\ Department of Pharmacology and Institute of Gastroenterology, Brain Korea 21 Project for Medical Sciences, \\ Yonsei University College of Medicine, Seoul, Korea
}

\begin{abstract}
SUMMARY: Reactive oxygen species (ROS) has been considered to be an important regulator in the development and pathogenesis of pancreatitis and an activator of the transcription factor, nuclear factor- $\kappa \mathrm{B}(\mathrm{NF}-\kappa \mathrm{B})$, regulating inflammatory cytokine gene expression. NF- $\kappa \mathrm{B}$ activation was demonstrated in cerulein pancreatitis, which rapidly induces an acute, edematous form of pancreatitis. This study aimed to investigate whether cerulein induced ROS generation, lipid peroxide and hydrogen peroxide production, NF- $\kappa$ B activation, and expression of cytokines (IL-1 $\beta$, IL-6) in pancreatic acinar cells. An additional aim was to establish whether these alterations were inhibited by antioxidants such as glutathione, superoxide dismutase, and catalase and an inhibitor of NF- $\kappa$ B activation, pyrrolidine dithiocarbamate (PDTC). To determine the possible interactions of the antioxidants and PDTC with cerulein-induced signaling, $\mathrm{Ca}^{2+}$ signal and amylase release were monitored in the pancreatic acinar cells treated with cerulein in the presence or absence of either the antioxidants or PDTC. The results showed that cerulein generated ROS and increased lipid peroxide and hydrogen peroxide production in the acinar cells, as determined by dichlorofluorescein diacetate dye. This resulted in NF- $\kappa \mathrm{B}$ activation and the induction of cytokine gene expression in the cells. The cerulein-induced NF- $\kappa \mathrm{B}$ activation was in parallel to $\mathrm{I}_{\kappa} \mathrm{B} \alpha$ degradation. Cerulein also induced $\mathrm{Ca}^{2+}$ signals and amylase release in acinar cells. Both antioxidants (glutathione, superoxide dismutase, catalase) and PDTC inhibited the cerulein-induced, oxidant-mediated alterations but did not affect the cerulein-evoked $\mathrm{Ca}^{2+}$ signals and amylase release in acinar cells. In conclusion, ROS, generated by cerulein, activates NF- $\kappa \mathrm{B}$, resulting in the up-regulation of inflammatory cytokine gene expression in acinar cells. NF- $\kappa$ B inhibition by scavenging ROS might alleviate the inflammatory response in pancreatic acinar cells by suppressing cytokine gene expression. (Lab Invest 2002, 82:1359-1368).
\end{abstract}

$I$

t has been suggested that reactive oxygen species (ROS) play a role in the pathogenesis of acute pancreatitis (Schoenberg et al, 1990). Mounting evidences suggest that pancreatic oxidative stress occurs during the early stage of induction (Gough et al, 1990; Nonaka et al, 1990). Scavenger therapy for ROS has attained some success in experimental pancreatitis models (Nonaka et al, 1991; Sanfey et al, 1985; Wisner et al, 1988). In human acute pancreatitis, increased levels of lipid peroxidation products in the bile or pancreatic tissue (Guyan et al, 1990; Schoenberg et al, 1988, 1995a) and subnormal levels of antioxidant vitamins in the blood (Schoenberg et al, 1995b; Scott et al, 1993) have been reported. Once produced, ROS can act as a molecular trigger of various inflammatory processes. They can attack the biologic membranes directly, triggering the accumulation of neutrophils (Petrone et al, 1980) and their adherence to the capillary wall (Bjork and Arfors, 1982). Therefore, it is probable that ROS play a central role in perpetuating pancreatic inflammation and the

DOI: 10.1097/01.LAB.0000032377.09626.C7

Received June 6, 2002.

This work was supported by a grant from Korea Research Foundation made in the program year of 2001 .

Address reprint requests to: Dr. Hyeyoung Kim, Department of Pharmacology, Yonsei University College of Medicine, Seoul 120-752, Korea. E-mail: Kim626@yumc.yonsei.ac.kr development of extrapancreatic complications (Guice et al, 1989).

Nuclear factor $-\kappa \mathrm{B}(\mathrm{NF}-\kappa \mathrm{B})$ is a pleiotropic transcription factor regulating the activation of a wide variety of genes that respond to immune or inflammatory signals including cytokine expression (Barnes and Karin, 1997; Wulczyn et al, 1996). NF- $\kappa$ B represents a family of proteins sharing the Rel homology domain, which bind to DNA as homodimers or heterodimers, and activates a multitude of cellular stress-related and early response genes. NF- $\kappa \mathrm{B}$ is kept silent in the cytoplasm via an interaction with inhibitory proteins of the $I_{\kappa} \mathrm{B}$ family and is activated by a variety of agents, including cytokines, mitogens, and ROS (Meyer et al, 1993). Several antioxidants such as $\mathrm{N}$-acetylcysteine (Ho et al, 1999; Schenk et al, 1994) and pyrrolidine dithiocarbamate (PDTC) (Bessho et al, 1994; Blackwell et al, 1996; Schreck et al, 1992) potentially inhibit $\mathrm{NF}-\kappa \mathrm{B}$ activation and/or NF- $\kappa \mathrm{B}$ interaction with its upstream regulatory binding site, thereby preventing $\mathrm{NF}-\kappa \mathrm{B}-\mathrm{mediated}$ transcriptional activation. Stimulated neutrophil-induced $\mathrm{NF}-\kappa \mathrm{B}$ activation was shown to be inhibited by $\mathrm{N}$-acetylcysteine in isolated rat pancreatic acinar cells (Kim et al, 2000). These studies reported that antioxidants might inhibit cytokine production by suppressing the oxidant-mediated activation of the transcription factor(s). Recently, the involvement of NF- $\kappa \mathrm{B}$ activation was proposed in experimental pancreatitis using cerulein, a cholecys- 
tokinin analog (Gukovsk et al, 1998; Steinle et al, 1999). Among a number of animal models of experimental pancreatitis that exhibit biochemical, morphologic, and pathophysiologic similarities to various aspects of human pancreatitis, cerulein pancreatitis was shown to be one of the best characterized and widely used experimental models (Gorelick et al, 1993; Willemer et al, 1992). Doses of cholecystokinin or cerulein beyond those that cause the maximum pancreatic secretion of amylase and lipase (Jensen et al, 1989; Sato et al, 1989) result in pancreatitis, which is characterized by a dysregulation of the production and secretion of digestive enzymes, particularly the inhibition of pancreatic secretion, and an elevation in their serum levels, cytoplasmic vacuolization and the death of acinar cells, edema formation, and an infiltration of inflammatory cells into the pancreas (Gorelick et al, 1993; Lerch and Adler, 1994; Willemer et al, 1992).

However, the mechanism of cerulein action in pancreatic acinar cells has not been determined. Although the earliest events that trigger acute pancreatitis are unclear, the key events seem to be a premature, intrapancreatic activation of digestive enzyme granules (Rinderknecht, 1993). The cerulein-evoked increase in intracellular $\mathrm{Ca}^{2+}$ levels is believed to be the main intracellular signal for enzyme and fluid secretion (Kanno, 1998). One interesting report showed the role of ROS on altering the cytoskeleton function in the pancreas (Jungerman et al, 1995). This cytoskeletal disruption may induce disturbances in the intracellular transport of digestive enzymes, leading to their premature intracellular activation (Dabrowski et al, 1999).

This study aimed to investigate pancreatic acinar cells to determine whether cerulein induces ROS generation and, therefore, increases lipid peroxide (LPO) and hydrogen peroxide $\left(\mathrm{H}_{2} \mathrm{O}_{2}\right)$ production, NF- $\kappa \mathrm{B}$ activation, and cytokine expression and whether these alterations are inhibited by antioxidants such as glutathione (GSH), superoxide dismutase (SOD), catalase, and an inhibitor of NF- $\kappa \mathrm{B}$ activation, PDTC. In addition, both $\mathrm{Ca}^{2+}$ signal and amylase release were monitored in pancreatic acinar cells treated with cerulein in the presence or absence of antioxidants or PDTC to determine the possible interaction of the antioxidants and PDTC with ceruleininduced signaling. Finally, the changes in the IL-6 level in the medium were observed both before and after removing the antioxidants and PDTC from the cells treated with cerulein to determine the reversibility of the inhibitory effects of these antioxidants and PDTC on cerulein-induced IL-6 production.

\section{Results}

\section{ROS Generation Using Fluorescence of Acinar Cells Treated with Cerulein}

The fluorescent products of the freshly isolated acinar cells (None) were assessed after incubation with dichlorofluorescein (DCF) diacetate (Fig. 1A). Treatment of the acinar cells with GSH resulted in the distribution of fluorescence from the right to the left (Fig. 1A).
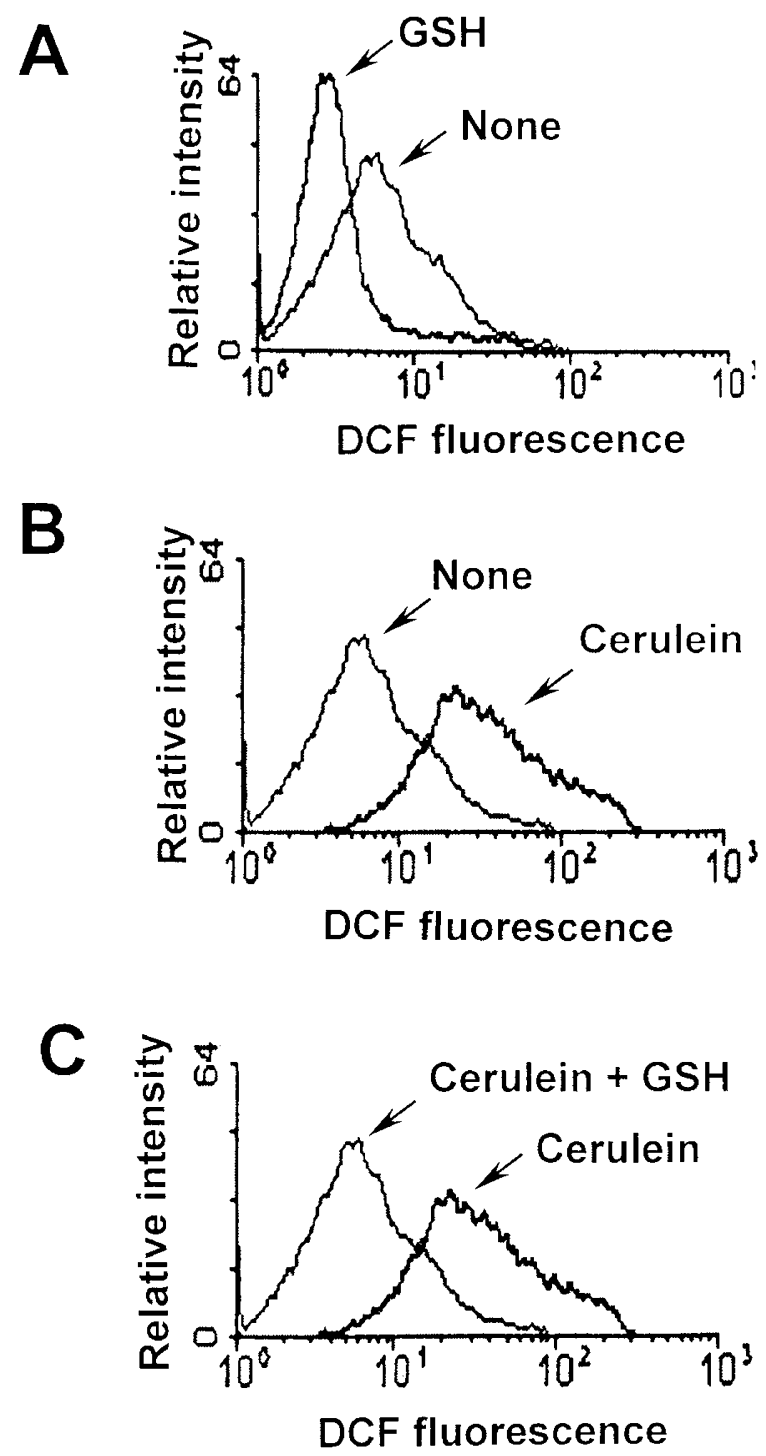

Figure 1.

Reactive oxygen species (ROS) generation using the fluorescence of the acinar cells treated with cerulein. The acinar cells were treated without (A) or with (B and $\mathrm{C}$ ) cerulein at a concentration of $10^{-8} \mathrm{M}$ in the presence or absence of glutathione (GSH) (10 mm) for 30 minutes. ROS generation was detected by the relative fluorescence intensity as a result of the oxidation of the reduced dichlorofluorescein (DCF) in the cells. None $=$ the acinar cells without treatment; $G S H=$ the cells treated with glutathione (GSH) alone; Cerulein = the cells treated with cerulein alone; Cerulein $+G S H=$ the cells treated with cerulein and GSH; DCF = dichlorofluorescein.

Cerulein moved the fluorescence distribution of normal cells (None) to the right (Fig. 1B), which was shifted left after an additional GSH treatment (Fig. 1C). These results indicate that cerulein generated ROS production in the acinar cells. GSH treatment $(10 \mathrm{~mm})$ prevented the cerulein-induced ROS generation in acinar cells.

\section{Concentration and Time Response of Acinar Cells to Cerulein for Cytokine mRNA Expression}

After a 3-hour culture, the acinar cells treated with various concentrations of cerulein $\left(10^{-11}\right.$ to $\left.10^{-7} \mathrm{M}\right)$ exhibited concentration-dependent mRNA expres- 
sions of IL- 6 and IL-1 $\beta$ (Fig. 2A). mRNA expression of IL-6 became evident at $10^{-11} \mathrm{M}$ of cerulein, which increased at $10^{-9}$ and $10^{-8} \mathrm{M}$ cerulein in the acinar cells. IL- $1 \beta$ mRNA expression was induced at $10^{-10} \mathrm{M}$ cerulein, which increased at $10^{-8} \mathrm{M}$ and $10^{-7} \mathrm{M}$ of cerulein. Figure 2B shows the time-dependent increase in the mRNA expressions of IL- 6 and IL- $1 \beta$ in the acinar cells treated with cerulein $\left(10^{-8} \mathrm{M}\right)$. mRNA expressions of both cytokines were evident at 2 hours and increased after 3 hours.

\section{Productions of LPO and IL-6 in Acinar Cells Treated with Cerulein}

Cerulein $\left(10^{-8} \mathrm{M}\right)$ induced production of LPO and IL-6 in the acinar cells time dependently (Fig. 3). LPO production occurred in parallel to IL-6 production. The LPO level reflects the oxidative damage of the cells. The LPO levels in the culture medium $(\mathrm{nmol} / \mathrm{ml})$ from the acinar cells treated with cerulein $\left(10^{-8} \mathrm{M}\right)$ at the beginning of the experiment and at 2, 4, 6, 8, and 16 hours of culture were $0.17 \pm 0.02,0.48 \pm 0.05,0.61 \pm$ $0.04,0.67 \pm 0.03,2.07 \pm 0.04$, and $2.86 \pm 0.05$, respectively. The LPO levels in the medium from the untreated cells (None) were $0.17 \pm 0.01,0.20 \pm 0.01$, $0.28 \pm 0.02,0.28 \pm 0.02,0.32 \pm 0.01$, and $0.33 \pm$ 0.02 at $0,2,4,6,8$, and 16 hours of culture, respectively (Fig. 3A). The IL-6 levels in the culture medium $(\mathrm{pg} / \mathrm{ml})$ from the acinar cells treated with cerulein $\left(10^{-8} \mathrm{M}\right)$ at the start of the experiment and at 2, 4, 6, 8, and 16 hours of culture were $4.4 \pm 0.3,57.9 \pm 0.9$, $62.9 \pm 1.5,98.7 \pm 2.0,132.2 \pm 1.6$, and $262.7 \pm 7.3$, respectively. The IL-6 levels in the medium from the cells not treated (None) were $4.7 \pm 0.2,9.9 \pm 0.4,9.5$ $\pm 2.5,9.1 \pm 3.8,15.9 \pm 1.2$, and $18.4 \pm 1.2$ at $0,2,4$, 6,8 , and 16 hours of culture, respectively (Fig. 3B). These results suggest a possible relationship between ROS generation and the production of inflammatory

A

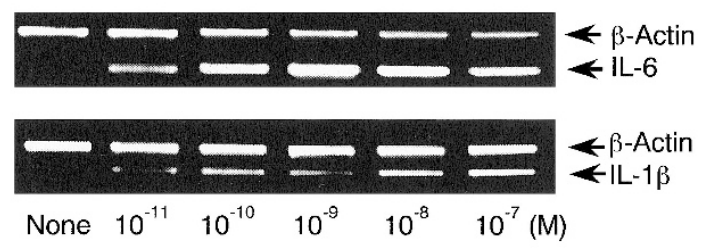

B

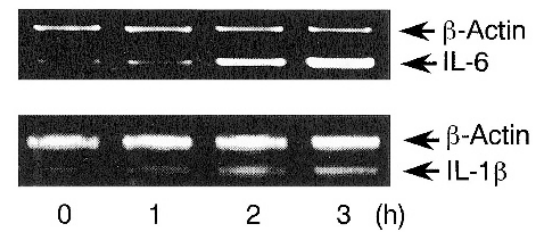

Figure 2.

Concentration and time response of acinar cells to cerulein for IL- 6 and IL-1 $\beta$ mRNA expression, as determined by RT-PCR. The acinar cells were treated with various concentrations of cerulein $\left(10^{-11}\right.$ to $\left.10^{-7} \mathrm{M}\right)$, and the cytokine mRNA expression was determined after a 3-hour culture (A). Cytokine mRNA expression in the acinar cells treated with cerulein $\left(10^{-8} \mathrm{M}\right)$ was assessed at an indicated time point (B). The internal standard ( $\beta$-actin) was coamplified with each cytokines. None $=$ acinar cells without treatment.
A

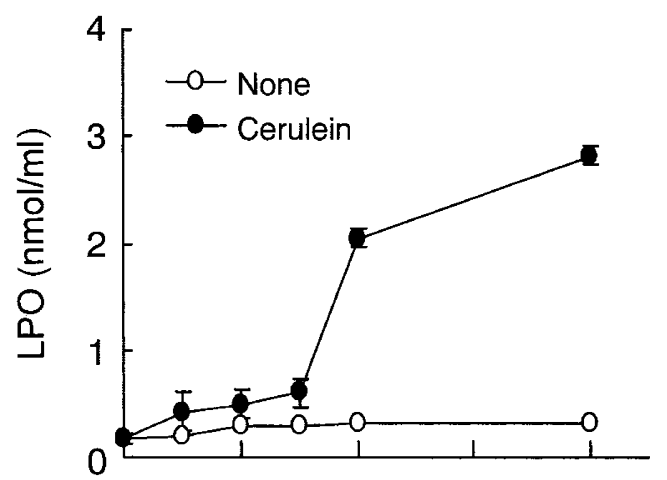

B

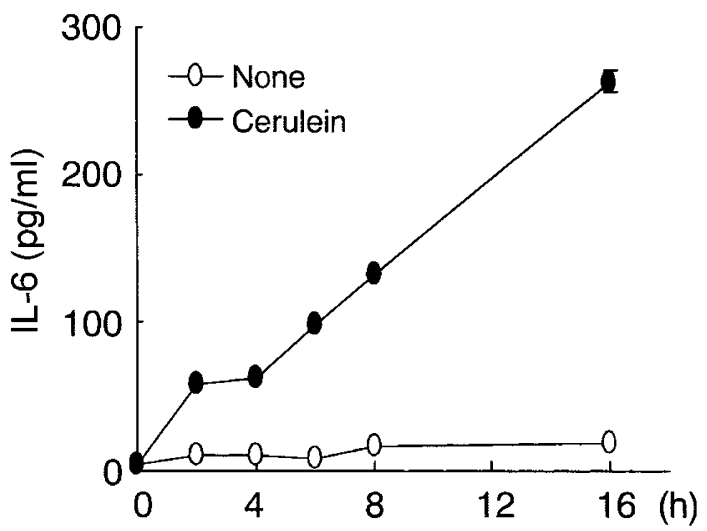

Figure 3.

Time response of the acinar cells for the lipid peroxide (LPO) and IL-6 levels to cerulein. The acinar cells were treated without or with cerulein $\left(10^{-8} \mathrm{M}\right)$, and the LPO (A) and IL-6 (B) levels in the medium released from the acinar cells were determined at the indicated time point. Each point represents means \pm SE of triplicate samples from three different experiments. None $=$ acinar cells without treatment; Cerulein $=$ the cells treated with cerulein alone.

cytokines such as IL- 6 and IL- $1 \beta$ in the acinar cells by cerulein treatment. This hypothesis was confirmed by the following experiments investigating the effects of antioxidants on IL-6 production in acinar cells treated with cerulein.

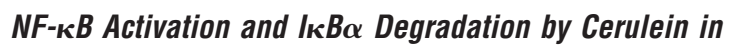 Acinar Cells}

To investigate the time response of acinar cells for NF- $\kappa \mathrm{B}$ activation, acinar cells were cultured for 3 hours with cerulein (Fig. 4). Cerulein induced NF- $\kappa$ B activation after 30 minutes, which was then reduced to the basal level during the 3-hour culture period. This phenomenon occurred in parallel with the $I_{\kappa} \mathrm{B} \alpha$ degradation observed in acinar cells caused by cerulein after 30 minutes. The $I_{\kappa} \mathrm{B} \alpha$ levels returned to the basal level after 1 hour, which continued for 3 hours.

\section{Effects of Antioxidants and PDTC on $\mathrm{H}_{2} \mathrm{O}_{2}$ Production in Acinar Cells Treated with Cerulein}

Cerulein $\left(10^{-8} \mathrm{M}\right)$ increased $\mathrm{H}_{2} \mathrm{O}_{2}$ production in acinar cells after a 16-hour culture. The $\mathrm{H}_{2} \mathrm{O}_{2}$ level in the medium $(\mathrm{nmol} / \mathrm{ml})$ from the acinar cells alone was 0.18 \pm 0.06 , which increased to $10.89 \pm 1.22$ after cerulein 


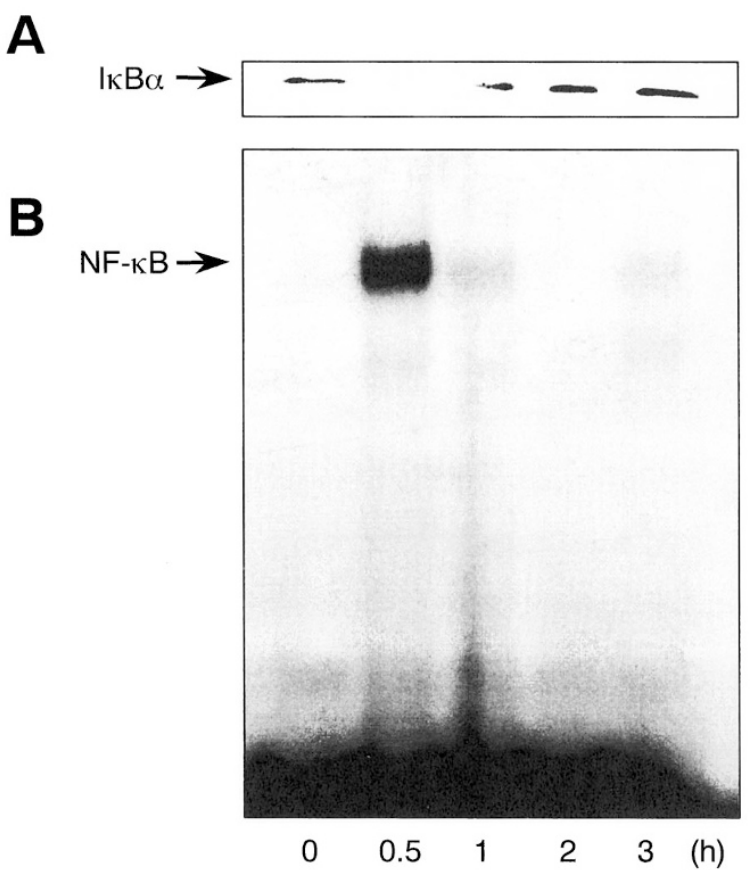

Figure 4.

The time course of nuclear factor $-\kappa \mathrm{B}(\mathrm{NF}-\kappa \mathrm{B})$ activation and $\mathrm{I}_{\kappa} \mathrm{B} \alpha$ degradation in the acinar cells treated with cerulein. The acinar cells were treated with cerulein $\left(10^{-8} \mathrm{M}\right)$ and cultured for 3 hours. The NF- $\kappa$ B level in the nuclear extract was determined by an electrophoretic mobility shift assay (EMSA), whereas the $I_{\kappa} \mathrm{B} \alpha$ level in the cell lysate was analyzed by Western blot analysis at an indicated time point.

treatment. The $\mathrm{H}_{2} \mathrm{O}_{2}$ levels from the acinar cells treated with cerulein in the presence of $10 \mathrm{~mm} \mathrm{GSH}$, $100 \mu \mathrm{M}$ PDTC, $1000 \mathrm{U} / \mathrm{ml}$ of SOD, and $1000 \mathrm{U} / \mathrm{ml}$ of catalase were $0.80 \pm 0.03,6.70 \pm 1.10,0.50 \pm 0.04$, and $0.66 \pm 0.05$, respectively.

\section{Effects of Antioxidants and PDTC on mRNA Expression and Protein Level of Cytokine in Acinar Cells Treated with Cerulein}

As shown in Figure 5, cerulein $\left(10^{-8} \mathrm{M}\right)$ induced both IL-1 $\beta$ and IL-6 mRNA expression (Control) after a 3-hour culture. The cerulein-induced IL-6 mRNA ex-
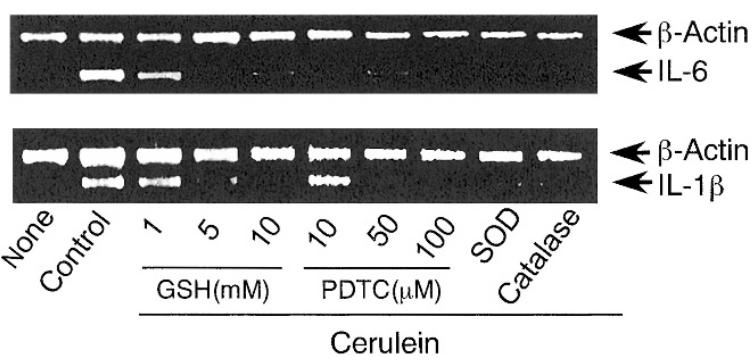

Figure 5.

Effects of antioxidants and pyrrolidine dithiocarbamate (PDTC) on IL-6 and $\mathrm{IL}-1 \beta$ mRNA expression in the acinar cells treated with cerulein. The acinar cells were treated without or with cerulein $\left(10^{-8} \mathrm{M}\right)$ in the presence of GSH, PDTC, superoxide dismutase (SOD), or catalase for 3 hours. Cytokine mRNA expression was determined by RT-PCR. The internal standard ( $\beta$-actin) was coamplified with each cytokine. None = acinar cells without treatment; Control $=$ acinar cells treated with cerulein alone. pression was inhibited by GSH (5 and $10 \mathrm{~mm}$ ), PDTC $(10,50$, and $100 \mu \mathrm{M})$, SOD $(1000 \mathrm{U} / \mathrm{ml})$, and catalase (1000 U/ml). The cerulein-induced IL-1 $\beta$ expression was inhibited by GSH (5 and $10 \mathrm{~mm}$ ), PDTC (50 and $100 \mu \mathrm{M})$, SOD, and catalase (Fig. 5). IL-6 protein production increased in the acinar cells treated with cerulein for 16 hours, which was inhibited by GSH (5 and $10 \mathrm{~mm})$, PDTC (10, 50, and $100 \mu \mathrm{m})$, SOD, and catalase (Fig. 6). IL-6 levels in the culture medium $(\mathrm{pg} / \mathrm{ml})$ from the acinar cells alone was $25.4 \pm 3.4$, which increased to $223.4 \pm 15.3$ after cerulein treatment. The IL-6 levels from the acinar cells treated with cerulein in the presence of 1,5 , and $10 \mathrm{~mm}$ of GSH were $192.1 \pm 44.0,100.5 \pm 11.6$, and $44.6 \pm 6.5$, respectively, whereas those from the cells treated with cerulein in the presence of 10,50 , and $100 \mu \mathrm{M}$ of PDTC were $75.9 \pm 8.5,40.2 \pm 2.0$, and $40.0 \pm 8.7$, respectively. Each $1000 \mathrm{U} / \mathrm{ml}$ of SOD and catalase inhibited the cerulein-induced increase in the IL-6 protein levels (223. $4 \pm 15.3)$ to $46.9 \pm 2.1$ and $91.5 \pm$ 1.5 , respectively.

\section{The Reversibility of the Inhibitory Effects of Antioxidants and PDTC on Cerulein-Induced IL-6 Production in Acinar Cells}

To determine the reversibility of the inhibitory effects of the antioxidants and PDTC on the cerulein-induced IL-6 production, the IL-6 level in the medium was measured before and after removing the antioxidants and PDTC from the cells treated with cerulein. As shown in Figure 7, the inhibitory effects of the antioxidants and PDTC on cerulein-induced IL-6 production were rapidly washed out. After a 16-hour treatment with the antioxidants and PDTC, a potent inhibitory effect on the cerulein-induced IL-6 production was observed. The inhibitory effect of the antioxidants and

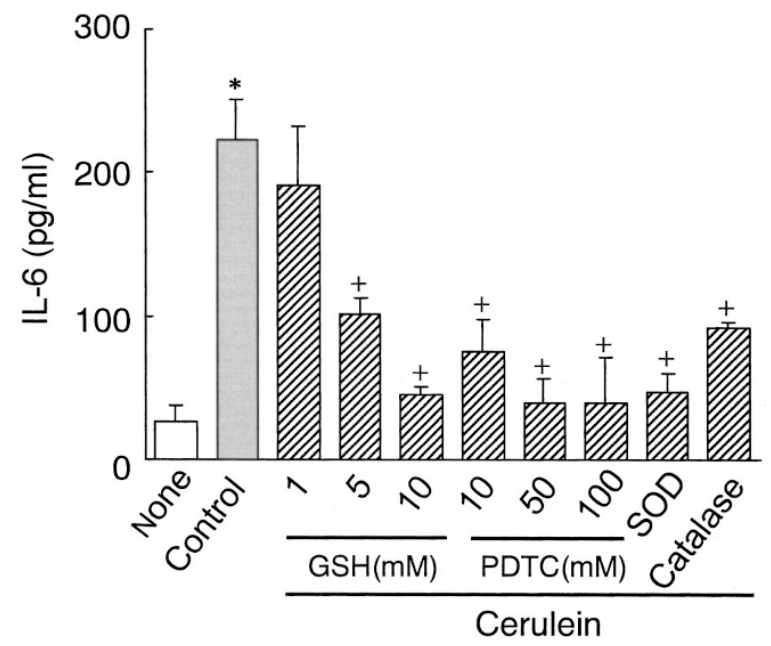

Figure 6 .

Effects of antioxidants and PDTC on the IL-6 level in the acinar cells treated with cerulein. The acinar cells were treated without or with cerulein $\left(10^{-8} \mathrm{M}\right)$ in the presence of GSH, PDTC, SOD, or catalase for 16 hours. The IL-6 level was determined by an ELISA. None = acinar cells without treatment; Control $=$ acinar cells treated with cerulein alone. ${ }^{*} p<0.05$ versus none; $+p<0.05$ versus control. 


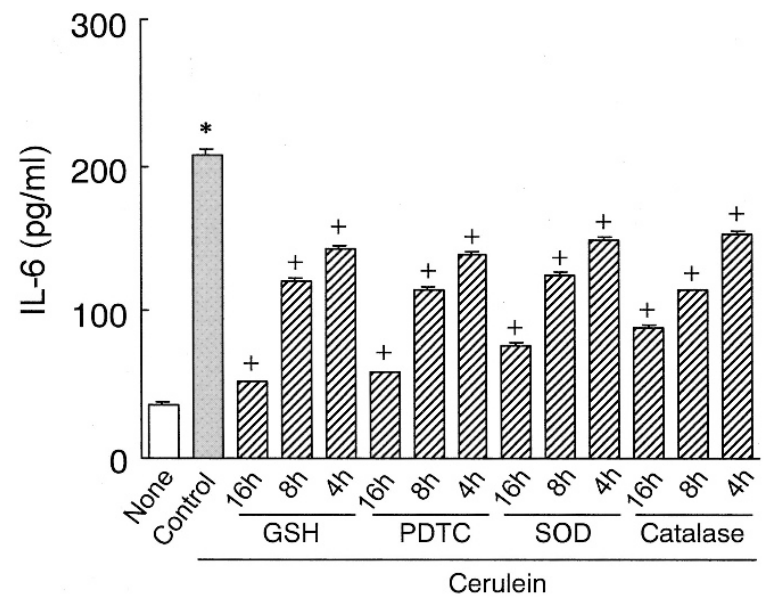

Figure 7.

Reversibility of the inhibitory effects of the antioxidants and PDTC on cerulein-induced IL-6 production in acinar cells. GSH (10 mm), SOD (1000 $\mathrm{U} / \mathrm{ml})$, catalase $(1000 \mathrm{U} / \mathrm{ml})$, or PDTC $(100 \mu \mathrm{M})$ were added to the cells for 16 , 8 , or 4 hours in the presence of cerulein $\left(10^{-8} \mathrm{M}\right)$. After the 16-hour treatment with drugs in the presence of cerulein, the medium was collected for the IL-6 determination. For the drug treatment in the presence of cerulein for 8 and 4 hours, the cells were exposed to cerulein only (without drugs) and cultured for a further 8 and 12 hours. The total culture period for all the cells was 16 hours in the presence of cerulein, but with a different exposure period to the antioxidants and PDTC. The IL-6 levels were determined in the medium by ELISA. None $=$ acinar cells without treatment; Control $=$ acinar cells treated with cerulein alone; $16 h=16$-hour treatment of drugs in the presence of cerulein; $8 h=8$-hour treatment of drugs in the presence of cerulein and no treatment for another 8 hours in the presence of cerulein; $4 h=4$-hour treatment of drugs in the presence of cerulein and no treatment for a further 12 hours in the presence of cerulein. ${ }^{*} p<0.05$ versus none; $+p<0.05$ versus control.

PDTC was relatively low when the cerulein-treated cells were cultured for 4 hours in the presence of the antioxidants and PDTC and then cultured for a further 12 hours in the absence of the antioxidants and PDTC. After removing the antioxidants and PDTC from the culture medium, IL- 6 production was restored in the cells by cerulein.

\section{Effects of Antioxidants and PDTC on Cerulein-Induced NF-кB Activation in Acinar Cells}

After 30 minutes of stimulation, which was the highest level of cerulein-induced NF- $\kappa \mathrm{B}$ activation, the increased $\mathrm{NF}-\kappa \mathrm{B}$ levels in the nucleus were reduced by treatment with the antioxidants and PDTC. Relatively large degrees of inhibition on the cerulein-induced $\mathrm{NF}-\kappa \mathrm{B}$ activation was shown after $\mathrm{GSH}$ (5 and $10 \mathrm{~mm}$ ), PDTC (50 and $100 \mu \mathrm{M})$, SOD, and catalase treatment (Fig. 8).

\section{Effects of Antioxidants and PDTC on Cerulein-Induced Amylase Release from Acinar Cells}

Cerulein induced amylase release time dependently (Fig. 9A). The amylase levels in the medium (IU/ml) from the acinar cells treated with cerulein at the beginning of the experiments and at 2, 4, 6, 8, and 16 hours of culture were $0.6 \pm 0.2,6.5 \pm 0.6,33.6 \pm 6.8$, $63.9 \pm 3.6,94.5 \pm 5.2$, and $101.6 \pm 6.5$, respectively. Amylase release from the cells without cerulein treat-

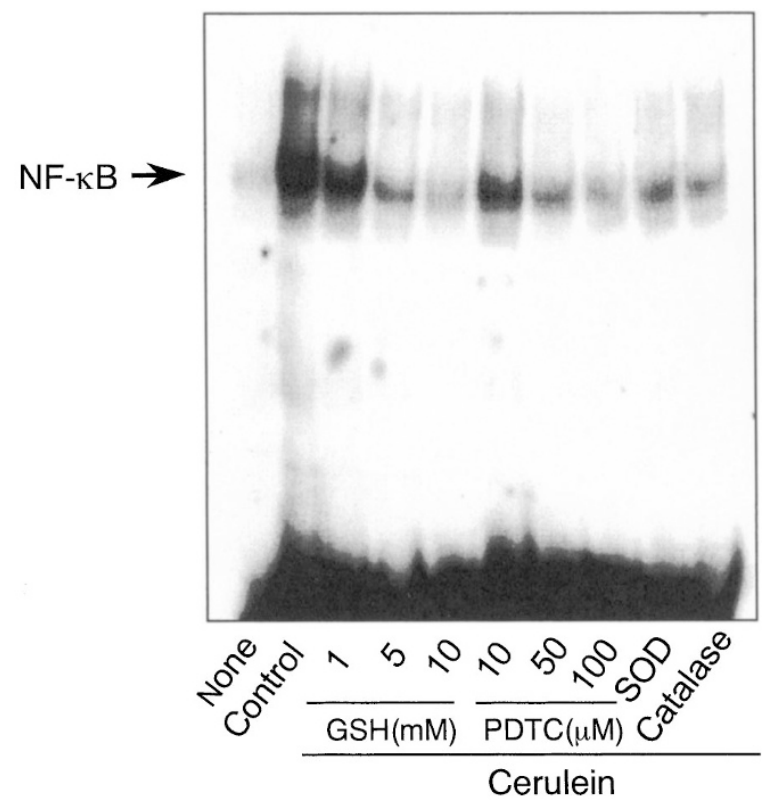

Figure 8.

Effects of antioxidants and PDTC on NF- $\kappa$ B activation of acinar cells treated with cerulein. The acinar cells were treated with or without cerulein $\left(10^{-8} \mathrm{M}\right)$ in the presence of GSH, PDTC, SOD, or catalase for 30 minutes. NF- $\kappa$ B activation was determined by an EMSA. None = acinar cells without treatment; Control $=$ acinar cells treated with cerulein alone.

ment (None) remained unchanged during the culture period. After 16 hours of culturing, neither the antioxidants nor PDTC affected the cerulein-induced amylase release (Fig. 9B).

\section{Effects of Antioxidants and PDTC on Cerulein-Induced $\mathrm{Ca}^{2+}$ Signal from Acinar Cells}

The cerulein-evoked $\mathrm{Ca}^{2+}$ signals and the increased intracellular $\mathrm{Ca}^{2+}$ levels in acinar cells were determined by the ratio of fluorescence excited at $350 \mathrm{~nm}$ and $380 \mathrm{~nm}$. A relatively high cerulein dose $\left(10^{-8} \mathrm{M}\right)$ evoked an initial peak in the $\mathrm{Ca}^{2+}$ signal and did not induce a further $\mathrm{Ca}^{2+}$ signal (Fig. 10A). Treatment with both the antioxidants and PDTC did not affect the cerulein-induced $\mathrm{Ca}^{2+}$ signal in the acinar cells (Fig. $10, B$ to $E)$.

\section{Discussion}

The main finding of this study are as follows. (1) Cerulein generates ROS and induces LPO and $\mathrm{H}_{2} \mathrm{O}_{2}$ production, NF- $\kappa \mathrm{B}$ activation, and production of the inflammatory cytokines (IL-1 $\beta, \mathrm{IL}-6)$ in pancreatic acinar cells. (2) Antioxidants such as GSH, SOD, and catalase and an inhibitor of NF- $\kappa$ B activation, PDTC, suppressed LPO and $\mathrm{H}_{2} \mathrm{O}_{2}$ production and the oxidant-mediated activation of $\mathrm{NF}-\kappa \mathrm{B}$, thereby decreasing the cytokine gene expression induced by cerulein. However, both antioxidants and PDTC affected neither the cerulein-evoked $\mathrm{Ca}^{2+}$ signal nor the amylase release in the acinar cells. In addition, the inhibitory effects of the antioxidants and PDTC on IL-6 production were reversible. This suggests the involve- 
A

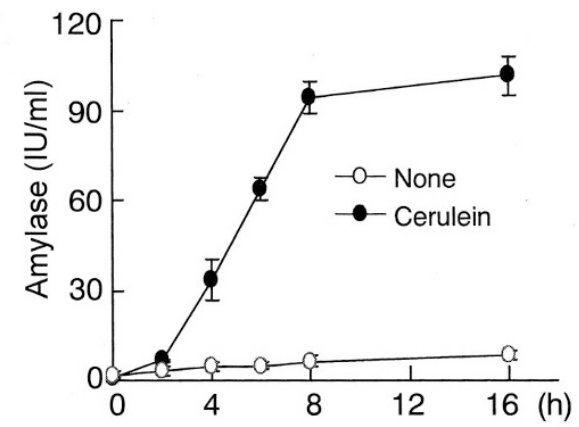

B

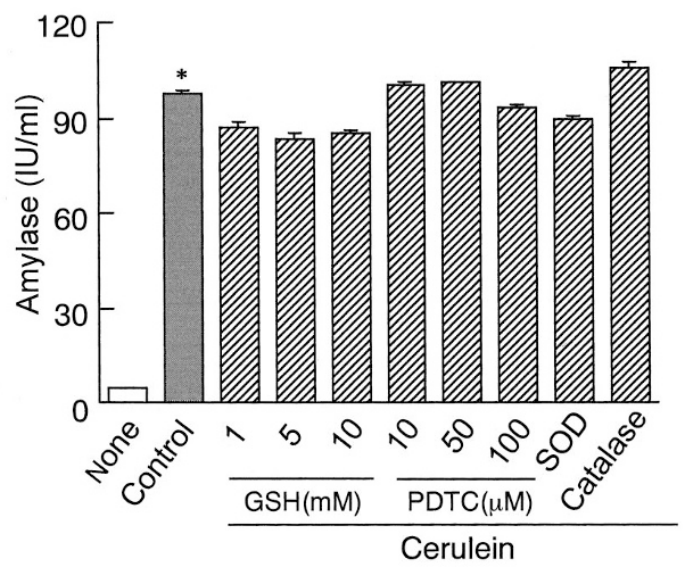

Figure 9.

Time response of the acinar cells to cerulein for amylase release and the effects of the antioxidants and PDTC on the cerulein-induced amylase release from the acinar cells. The acinar cells were treated with or without cerulein $\left(10^{-8} \mathrm{M}\right)$, and the amylase level in the medium released from the acinar cells was determined at the indicated time point $(A)$. To investigate the effect of the antioxidants and PDTC, the acinar cells treated with cerulein $\left(10^{-8} \mathrm{M}\right)$ were cultured in the absence (Control) or the presence of GSH, SOD, catalase, or PDTC. The amylase level was determined in the medium after a 16-hour culture (B). Each point represents means \pm SE of triplicate samples from three different experiments. None $=$ acinar cells without treatment; Control $=$ the cells treated with cerulein alone.

ment of ROS, which activates NF- $\kappa \mathrm{B}$, a central mediator of the inflammatory response, in cerulein-induced pancreatitis in vitro.

ROS is an important mediator in the initiation and development of pancreatitis (Aho et al, 1982; Okumura et al, 1982; Uys et al, 1973). Among the ROS, $\mathrm{H}_{2} \mathrm{O}_{2}$ is suggested to be a mediator of oxidant-mediated $\mathrm{NF}-\kappa \mathrm{B}$ activation. A possible step responsible for the oxidative stress is $I_{\kappa} \mathrm{B}$ phosphorylation (Neurath et al, 1998). In addition, the polyubiquitination and proteasome degradation process might be sensitive to oxidative stress (Li and Karin, 1999). Apparently, more studies to determine what steps are affected by the ROS during NF- $\kappa \mathrm{B}$ activation need to be performed. In this study, ROS generated from cerulein resulted in prompt NF- $\kappa \mathrm{B}$ activation and increased LPO production. The onset of $\mathrm{NF}-\kappa \mathrm{B}$ activation correlated with $\mathrm{I}_{\kappa} \mathrm{B} \alpha$ degradation after 30 minutes of treatment with cerulein. This indicates that $\mathrm{I}_{\kappa} \mathrm{B} \alpha$ is responsible for controlling the nuclear translocation of NF- $\kappa \mathrm{B}$ in the
A

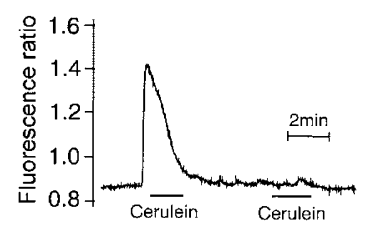

C

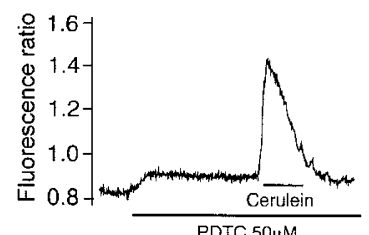

$E$

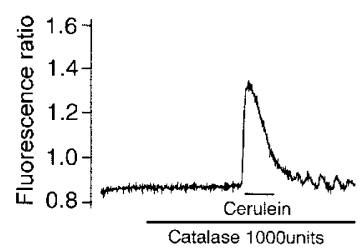

Figure 10.

Effects of antioxidants and PDTC on the cerulein-induced $\mathrm{Ca}^{2+}$ signal from the acinar cells. Fura-2-loaded acinar cells were superfused with a standard perfusate and then perfused with standard perfusate containing cerulein $\left(10^{-8}\right.$ м) alone or cerulein in the presence of either the antioxidants or PDTC. The free cytosolic concentration of $\mathrm{Ca}^{2+}$ was determined by the Fura-2 fluorescences excited at 350 and $380 \mathrm{~nm}$ and expressed as the fluorescence ratio of 350 $\mathrm{nm} / 380 \mathrm{~nm}$.

pancreatic acinar cells. These results are in agreement with a report demonstrating that $\mathrm{I}_{\kappa} \mathrm{B} \alpha$ and not $\mathrm{I}_{\kappa} \mathrm{B} \beta$ regulates the persistent response of NF- $\kappa \mathrm{B}$ activation in the pancreas (Steinle et al, 1999), even though changes in the $I_{\kappa} \mathrm{B} \beta$ levels in acinar cells after cerulein treatment were not determined in this study. The ROS generated from cerulein seems to be the main contributor to cytokine production in acinar cells by directly activating the oxidant-sensitive transcription factor, NF- $\kappa \mathrm{B}$. This study showed that the acinar cells on their own induced mRNA expressions of the cytokines (IL-1 $\beta$, IL-6) and IL-6 protein after cerulein treatment. Recent in vivo studies (Heath et al, 1993; Norman et al, 1994) suggest that intrapancreatic IL$1 \beta$, IL-6, and TNF- $\alpha$ are rapidly and coordinately increased during the early stages of acute pancreatitis. In the experimental pancreatitis in vivo, the inflammatory cytokines could be produced from the infiltrating inflammatory cells and the pancreatic cells including acinar cells. This study demonstrates the possibility of the direct production of inflammatory cytokines in pancreatic acinar cells by stimulation with secretagogues or during hypersecretion in the pancreas, such as acute pancreatitis.

$\mathrm{NF}-\kappa \mathrm{B}$ belongs to the Rel family of transcription factors that regulate the activation of the cellular stress-related and early-response genes such as cy- 
tokines, growth factors, adhesion molecules, and acute-phase proteins (Barnes and Karin, 1997; Wulczyn et al, 1996). The human Rel proteins include p50, p52, Rel (c-Rel), Rel A (p65), and Rel B. The classic form of the activated NF- $\kappa$ B is a heterodimer consisting of one p50 and one p65 subunit. Even though the composition of the NF- $\kappa \mathrm{B}$ activated by cerulein was not classified in this study, the induction of a nuclear translocation of a p50/p65 NF- $\kappa \mathrm{B}$ heterodimer and a p50 NF- $\kappa \mathrm{B}$ homodimer was previously identified in pancreatic acinar cells exposed to stimulated neutrophils (Kim et al, 2000). Further study aimed at clarifying the NF- $\kappa \mathrm{B}$ complex activated by cerulein in pancreatic acinar cells is recommended.

In an attempt to characterize the role of ROS and the induction of $\mathrm{NF}-\kappa \mathrm{B}$ activation, which is responsible for the productions of inflammatory cytokines in the acinar cells, the effects of known antioxidants such as GSH, SOD, and catalase on cerulein-induced alterations were investigated by comparing their effect with the effect of an inhibitor of NF- $\kappa$ B activation, PDTC. In this study, antioxidant treatment at a concentration that efficiently inhibited $\mathrm{H}_{2} \mathrm{O}_{2}$ production and blocked NF- $\kappa \mathrm{B}$ activation caused a decrease in cytokine expression induced by cerulein. These results suggest that antioxidants might inhibit the expression of the inflammatory cytokines by suppressing NF- $\kappa \mathrm{B}$ activation and/or the NF- $\kappa \mathrm{B}$ interaction with the upstream regulatory binding site of the cytokines such as IL-6 (Ben-Baruch et al, 1995; Wulczyn et al, 1996). When compared with the antioxidants used in the study, PDTC showed a relatively low inhibitory effect on $\mathrm{H}_{2} \mathrm{O}_{2}$ production caused by cerulein. PDTC is a quite potent NF- $\kappa \mathrm{B}$ inhibitor when compared with most antioxidants. The molecular basis of PDTC action has been attributed to its interaction with zinc (Kim et al, 1999) rather than its antioxidant or metal chelator activity (Bessho et al, 1994; Schreck et al, 1992).

In conclusion, the ROS, generated by cerulein, activates $\mathrm{NF}-\kappa \mathrm{B}$, resulting in an up-regulation of the inflammatory cytokine gene expression in pancreatic acinar cells. It is believed that NF- $\kappa \mathrm{B}$ inhibition by the scavenging ROS might alleviate the inflammatory response in pancreatic acinar cells by suppressing cytokine gene expression.

\section{Materials and Methods}

\section{Isolation of Pancreatic Acinar Cells}

Male Sprague-Dawley rats (150-200 g), inbred at the Yonsei University Medical Center animal unit, were used. The acinar cells were isolated by an enzymatic digestion of the pancreas, as described by Oliver et al (1987). The acinar cells were cultured in Ham's nutrient mixture F12 medium, with 15\% fetal bovine serum, $0.1 \mathrm{mg} / \mathrm{ml}$ of soybean trypsin inhibitor (Sigma Chemical Company, St. Louis, Missouri), and streptomycin at $0.1 \mathrm{mg} / \mathrm{ml}$ and penicillin at $100 \mathrm{U} / \mathrm{ml}$ in a $5 \% \mathrm{CO}_{2}$ and $95 \% \mathrm{O}_{2}$ atmosphere. The cell viability was deter- mined by the trypan blue dye exclusion test; more than $95 \%$ of the cells survived after 24 -hour culture.

\section{Experimental Protocol}

The acinar cells were plated at a density of $10^{6} / \mathrm{ml}$ in a 12-well tissue culture plate (Falcon 3047; Becton Dickinson Labware, Lincoln Park, New Jersey). To determine the concentration response of the acinar cells to cerulein, the cells were treated with cerulein at concentrations ranging from $10^{-11}$ to $10^{-7} \mathrm{M}$ and cultured for 3 hours. The mRNA expression of IL- 6 and IL- $1 \beta$ was determined by RT-PCR. The cells were treated with cerulein at $10^{-8} \mathrm{M}$ and cultured for 16 hours to determine the time response of the acinar cells to cerulein. The levels of LPO, IL-6, and amylase were determined in the medium using a fluorometric assay, ELISA, and a colorimetric assay at the beginning of the experiment and after 2, 4, 6, 8, and 16 hours of culture. The $\mathrm{H}_{2} \mathrm{O}_{2}$ levels were determined in the medium using a colorimetric assay after 16 hours of culture. The changes in the IL- 6 and IL-1 $\beta$ mRNA expression were monitored by RT-PCR for 3 hours with a 1-hour interval. The time response of the acinar cells to cerulein $\left(10^{-8} \mathrm{M}\right)$ for $\mathrm{NF}-\kappa \mathrm{B}$ activation and $\mathrm{I}_{\kappa} \mathrm{B} \alpha$ degradation was observed for 3 hours and determined by an electrophoretic mobility shift assay (EMSA) and Western blot analysis.

To investigate the effect of antioxidants and PDTC, the cerulein-treated $\left(10^{-8} \mathrm{M}\right)$ acinar cells were cultured in the absence (Control) or the presence of GSH $(1,5$, and $10 \mathrm{~mm})$, SOD $(1000 \mathrm{U} / \mathrm{ml})$, catalase $(1000 \mathrm{U} / \mathrm{ml})$, or PDTC $(10,50$, and $100 \mu \mathrm{M})$. The IL-6, $\mathrm{H}_{2} \mathrm{O}_{2}$, and amylase levels were determined in the medium after 16 hours of culture. Cytokine mRNA expression was determined in the acinar cells after 3 hours of culture. $\mathrm{NF}-\kappa \mathrm{B}$ activation was observed by EMSA after a 30-minute incubation. The culture times for determining the IL-6 protein level, cytokine mRNA expression, and $\mathrm{NF}-\kappa \mathrm{B}$ activation were decided based on the time-response experiments of the acinar cells to cerulein in this study. Before the experiment, the ability of cerulein to produce ROS in the acinar cells was determined using a DCF diacetate dye with flow cytometry, as described below.

In addition, to determine the possible interaction of the antioxidants and PDTC with cerulein-induced signaling, the $\mathrm{Ca}^{2+}$ signal was monitored in the pancreatic acinar cells treated with cerulein $\left(10^{-8} \mathrm{M}\right)$ in the presence or absence of GSH (5 mM), SOD (500 U/ml), catalase $(1000 \mathrm{U} / \mathrm{ml})$, or PDTC $(50 \mu \mathrm{M})$. Finally, changes in the IL- 6 level in the medium were observed before and after the removal of the antioxidants and PDTC from the cells treated with cerulein to determine the reversibility of the inhibitory effects of the antioxidants and PDTC on the cerulein-induced IL-6 production. Briefly, GSH (10 mm), SOD (1000 U/ml), catalase (1000 U/ml), or PDTC $(100 \mu \mathrm{M})$ were added to the cells for 16,8 , or 4 hours in the presence of cerulein $\left(10^{-8}\right.$ M). After the 16-hour treatment with drugs in the presence of cerulein, the medium was collected for IL-6 determination. For the drug treatment in the 
presence of cerulein for 8 and 4 hours, the cells were exposed only to cerulein without the drugs and cultured for a further 8 and 12 hours. The total culture period for all the cells was 16 hours in the presence of cerulein, but with a different exposure period to the antioxidants and PDTC. The IL-6 levels were determined in the medium.

\section{Flow Cytometric Assay Using DCF Diacetate}

The intracellular ROS was measured using the method reported by Bass et al (1983). Briefly, the acinar cells were plated at a density of $10^{6} / \mathrm{ml}$ in a 12 -well tissue culture plate and treated with cerulein at a concentration of $10^{-8} \mathrm{M}$ or without cerulein in the presence or absence of GSH (10 mm) for 30 minutes. The incubation time commenced from the time of NF- $\kappa \mathrm{B}$ activation after cerulein treatment in this study. The cells were washed with the culture medium without phenol red and incubated in Krebs-Ringer solution containing $50 \mu \mathrm{M}$ DCF diacetate in the dark for 5 minutes. DCF diacetate is a nonpolar compound that diffuses rapidly into the cells, where it hydrolyzes to the fluorescent polar derivative DCF, which is a reduced form. In the presence of a proper oxidant, the reduced form of DCF is oxidized to the highly fluorescent DCF. ROS generation was detected as a result of the oxidation of the reduced DCF in the cells using flow cytometry at $488 \mathrm{~nm}$ excitation and $515 \mathrm{~nm}$ emission. For the purpose of a visual comparison using a population histogram, each preparation was recorded at a single amplification setting of the photomultiplier gain.

\section{RT-PCR Analysis for IL-1 $\beta$ and IL-6}

IL-1 $\beta$ and IL-6 mRNA expression was assessed using RT-PCR standardized by coamplification with the housekeeping gene $\beta$-actin, which served as an internal control. The total RNA was isolated from the cells, treated with or without cerulein in the presence or absence of the antioxidants (GSH, SOD, catalase) or PDTC using the guanidine thiocyanate extraction method (Chomczynski and Sacchi, 1987). The total RNA was reverse transcribed into DNA and used for PCR with rat-specific primers for the cytokines (IL-1 $\beta$ and IL-6) and $\beta$-actin. The sequences of the IL-1 $\beta$ primers were $5^{\prime}$-TCCTAGGAAACAGCAATGGTCG-3' (forward primer) and 5'-TTCATCCCATACACACGGACAAC-3' (reverse primer), giving a 363-bp PCR product. The sequences of the IL-6 primers were 5'CTGGTCTTCTGGAGTTCCGTITC-3' (forward primer) and 5'-CATAGCACACTAGGTTTGCCGAG-3' (reverse primer), giving a 301-bp PCR product. For $\beta$-actin, the forward primer was 5'-ACCAACTGGGACGACATGGAG-3' and the reverse primer was 5'-GTGAGGATCTTCATGAGGTAGTC-3', giving a 349-bp PCR product (Nakajima-lijima et al, 1985). Briefly, the PCR was amplified by 32 repeat denaturation cycles at $95^{\circ} \mathrm{C}$ for 30 seconds, annealing at $60^{\circ} \mathrm{C}$ for 30 seconds, and extension at $72^{\circ} \mathrm{C}$ for 30 seconds. During the first cycle, the $95^{\circ} \mathrm{C}$ step was extended to 5 minutes. The PCR products were separated on
$1.5 \%$ agarose gels containing $0.5 \mu \mathrm{g} / \mathrm{ml}$ of ethidium bromide and visualized by UV transillumination.

\section{Determination of IL-6, LPO, $\mathrm{H}_{2} \mathrm{O}_{2}$, and Amylase}

The LPO, IL-6, and amylase levels in the medium were determined at the indicated time point. The $\mathrm{H}_{2} \mathrm{O}_{2}$ level was determined in the medium after a 16-hour culture. IL-6 level was determined using ELISA kits (R\&D System, Minneapolis, Minnesota). The LPO was measured as a thiobarbiturate reactive substance with a spectrofluorometer (SPF-500C; SLM Instruments, Urbana, Illinois) at $515 \mathrm{~nm}$ excitation and $553 \mathrm{~nm}$ emission (Yagi, 1976). The $\mathrm{H}_{2} \mathrm{O}_{2}$ level was determined using the method reported by Thurman et al (1972). The amylase levels in the medium were assessed and are expressed as IU/ml (Bernfeld, 1955).

\section{NF-кB Activation in Acinar Cells}

To determine the time response of the acinar cells for $\mathrm{NF}-\kappa \mathrm{B}$ activation, the acinar cells were seeded at $5 \times$ $10^{6}$ cells onto a $10-\mathrm{cm}$ culture dish and treated with cerulein $\left(10^{-8} \mathrm{M}\right)$ for 3 hours. A 30-minute stimulation was used to evaluate the effects of the antioxidants or PDTC on NF- $\kappa$ B activation because NF- $\kappa$ B activation was shown to be highest at 30 minutes. For the EMSA, the nuclear proteins were extracted from the acinar cells treated with or without cerulein in the presence or absence of the antioxidants (GSH, SOD, catalase) or PDTC, and an EMSA was performed according to the method reported by Dignam et al (1983). Briefly, the nuclear proteins were incubated with ${ }^{32} \mathrm{P}$-labeled DNA corresponding to the NF- $\kappa \mathrm{B}$ binding site of the igk gene (GATCGAGGGGGACTTTCCC TAGC; Santa Cruz Biotechnology, Santa Cruz, California) and poly(dl-dC) (Boehringer Mannheim, Indianapolis, Illinois). The mixtures were loaded onto a nondenaturing polyacrylamide gel and exposed to radiography film for 6 to 18 hours at $-70^{\circ} \mathrm{C}$. Quantitation of the $\mathrm{NF}-\kappa \mathrm{B}-\mathrm{DNA}$ binding activity was estimated using densitometry for the radioactivity of ${ }^{32} \mathrm{P}$ in the NF- $\kappa \mathrm{B}$ band. The control value was set to $100 \%$.

\section{Western Blot Analysis for IкBa in Acinar Cells}

For the time response of the acinar cells for $I_{\kappa} \mathrm{B} \alpha$ degradation, the acinar cells were seeded at $5 \times 10^{6}$ cells onto $10-\mathrm{cm}$ culture dish and treated with cerulein $\left(10^{-8} \mathrm{M}\right)$ for 3 hours. At the indicated time points, the cells were homogenized in Tris- $\mathrm{HCl}(\mathrm{pH}$ 7.4) buffer containing $0.5 \%$ Triton $\mathrm{X}-100$ and a protease inhibitor mixture (Boehringer-Mannheim). The protein concentration was measured using the method reported by Bradford (1976). Cellular protein $(100 \mu \mathrm{g})$ was loaded per lane, separated by $8 \%$ SDS-PAGE under reducing conditions and transferred onto nitrocellulose.

\section{Measurement of Intracellular $\mathrm{Ca}^{2+}$}

The free cytosolic concentration of $\mathrm{Ca}^{2+}$ was measured using Fura-2 (Molecular Probes, Eugene, Oregon) (Lee et al, 2000). Briefly, the Fura-2-loaded acinar 
cells were plated on coverslips forming the bottom of a perfusion chamber. After 2 to 3 minutes of incubation, the cells were superfused with a standard perfusate containing $140 \mathrm{~mm} \mathrm{NaCl}, 5 \mathrm{~mm} \mathrm{KCl}, 1 \mathrm{~mm}$ $\mathrm{MgCl}_{2}, 1 \mathrm{mM} \mathrm{CaCl}_{2}, 10 \mathrm{~mm}$ D-glucose, and $10 \mathrm{~mm}$ HEPES ( $\mathrm{pH}$ 7.4). The cells were then perfused with standard perfusate containing the antioxidants $(5 \mathrm{~mm}$ of GSH, $500 \mathrm{U} / \mathrm{ml}$ of SOD, $1000 \mathrm{U} / \mathrm{ml}$ of catalase) or 50 $\mu \mathrm{M}$ of PDTC. The Fura-2 fluorescences excited at 350 $\mathrm{nm}$ and $380 \mathrm{~nm}$ were measured using a photon counting system (PTI Delta Ram, Monmouth Junction, New Jersey).

\section{Statistical Analysis}

The statistical differences were determined using oneway ANOVA and Newman-Keul's test (Zar, 1984). All values are expressed as means $\pm \mathrm{SE}$. A $p$ value less than 0.05 was considered statistically significant.

\section{References}

Aho HJ, Nevalainen TJ, and Havia VT (1982). Human acute pancreatitis: A light and electron microscopic study. Acta Path Microbiol Immunol Scand Sect A 90:367-373.

Barnes PJ and Karin M (1997). Nuclear factor- $\kappa$ B: A pivotal transcription factor in chronic inflammatory diseases. $\mathrm{N}$ Engl J Med 336:1066-1071.

Bass DA, Parce JW, Dechatelet LR, Szejda P, Seeds MC, and Thomas M (1983). Flow cytometric studies of oxidative product formation by neutrophils: A graded response to membrane stimulation. J Immunol 130:1910-1917.

Ben-Baruch A, Michiel DF, and Oppenheim JJ (1995). Signals and receptors involved in recruitment of inflammatory cells. J Biol Chem 270:11703-11706.

Bernfeld P (1955). Amylase $\alpha$ and $\beta$. In: Colowick SP and Kaplan NO, editors. Methods in enzymology, vol. 1. New York: Academic Press, 149-150.

Bessho R, Matsubara K, Kubota M, Kuwakado K, Hirota H, Wakazono Y, Lin YW, Okuda A, Kawai M, Nishikomori R, and Heike T (1994). Pyrrolidine dithiocarbamate, a potent inhibitor of nuclear factor kappa B activation, prevents apoptosis in human promyelocytic leukemia HL-60 cells and thymocytes. Biochem Pharmacol 48:1883-1889.

Bjork $J$ and Arfors KE (1982). Oxygen free radicals and leukotriene $\mathrm{B}_{4}$ induced increase in vascular leakage is mediated by polymorphonuclear leukocytes. Agents Actions 11 (Suppl):63-72.

Blackwell TS, Blackwell TR, and Holden EP (1996). In vivo antioxidant treatment suppresses nuclear factor- $\kappa$ B activation and neutrophilic lung inflammation. J Immunol 157: 1630-1637.

Bradford MM (1976). A rapid and sensitive method for the quantitation of microgram quantities of protein utilizing the principle of protein-dye binding. Anal Biochem 72:248-254.

Chomczynski P and Sacchi N (1987). Single-step method of RNA isolation by acid guanidine isothiocyanate-phenolchloroform extraction. Anal Biochem 162:156-159.

Dabrowski A, Konturek SJ, Konturel JW, and Gabryelewicz A (1999). Role of oxidative stress in the pathogenesis of cerulein-induced acute pancreatitis. Eur J Pharmacol 377:111.

Dignam JD, Lebovitz RM, and Roeder RG (1983). Accurate transcription initiation by RNA polymerase II in a soluble extract from isolated mammalian nuclei. Nucleic Acids Res 11:1475-1489.

Gorelick FS, Adler G, and Kerin HF (1993). Cerulein-induced pancreatitis, 2nd ed. In: Go VW, DiMagno EP, Gardner JD, Lebenthal E, Reber HA, and Scheele GA, editors. The pancreas: Biology, pathobiology, and disease. New York: Raven Press, 501-526.

Gough DB, Boyle B, and Joyce WP (1990). Free radical inhibition and serial chemiluminescence in evolving experimental pancreatitis. Br J Surg 77:1256-1259.

Guice KS, Oldham KT, and Caty MG (1989). Neutrophildependent, oxygen-radical mediated lung injury associated with acute pancreatitis. Ann Surg 210:740-747.

Gukovsk I, Gukovskaya AS, and Blinman TA (1998). Early $\mathrm{NF}-\kappa \mathrm{B}$ activation is associated with hormone-induced pancreatitis. Am J Physiol 275:G1402-G1414.

Guyan PM, Udern S, and Braganza JM (1990). Heightened free radical activity in pancreatitis. Free Radic Biol Med 8:347-354.

Heath DL, Cruickshank DH, and Gudgeon M (1993). Role of interleukin- 6 in mediating the acute phase protein response and potential as an early means of severity assessment in acute pancreatitis. Gut 66:41-45.

Ho E, Chen G, and Bray TM (1999). Supplementation of $\mathrm{N}$-acetylcysteine inhibits NF- $\kappa \mathrm{B}$ activation and protects against alloxan-induced diabetes in CD-1 mice. FASEB $\mathrm{J}$ 13:1845-1854.

Jensen RT, Wank SA, Rowley WH, Sato S, and Gardner JD (1989). Interaction of CCK with pancreatic acinar cells. Trends Pharmacol Sci 10:418-423.

Jungerman J, Lerch MM, Weidenbach H, Lutz MP, and Adler $\mathrm{G}$ (1995). Dissemble of rat pancreatic acinar cell cytoskeleton during supramaximal secretagogue stimulation. Am J Physiol 268:G328-338.

Kanno T (1998). $\mathrm{Ca}^{++}$signal in the pancreatic acinus. Pancreas 16:273-276.

Kim CH, Kim JH, Hsu CY, and Ahn YS (1999). Zinc is required in pyrrolidine dithiocarbamate inhibition of $\mathrm{NF}-\kappa \mathrm{B}$ activation. FEBS Lett 449:28-32.

Kim H, Seo JY, Roh KH, Lim JW, and Kim KH (2000). Suppression of NF- $\kappa$ B activation and cytokine production by $\mathrm{N}$-acetylcysteine in pancreatic acinar cells. Free Radic Biol Med 29:674-683.

Lee MG, Ahn W, Choi JY, Luo X, Seo JT, Schultheis PJ, Shull GE, Kim KH, and Muallem S (2000). $\mathrm{Na}^{+}$- dependent transporter mediate $\mathrm{HCO} 3-$ salvage across the luminal membrane of the main pancreatic duct. J Clin Invest 105: 1651-1658.

Lerch MM and Adler G (1994). Experimental animal models of acute pancreatitis. Int J Pancreatol 15:159-170.

Li N and Karin M (1999). Is NF- $\kappa$ B the sensor of oxidative stress? FASEB J 13:1137-1143.

Meyer M, Schreck R, and Baeuerle PA (1993). Hydrogen peroxide and antioxidants have opposite effects on activa- 
tion of NF- $\kappa \mathrm{B}$ and $\mathrm{AP}-1$ in intact cells: $\mathrm{AP}-1$ as secondary antioxidant-responsive factor. EMBO J 12:2005-2015.

Nakajima-lijima S, Hamada H, Reddy P, and Kakunaga T (1985). Molecular structure of the human cytoplasmic $\beta$-actin gene: Interspecies homology of sequences in the introns. Proc Natl Acad Sci USA 82:6133-6137.

Neurath MF, Becker C, and Barbulescu K (1998). Role of $\mathrm{NF}-\kappa \mathrm{B}$ in immune and inflammatory responses in the gut. Gut 43:856-860.

Nonaka A, Manabe T, and Tamura K (1990). Organ specific ESR features in mouse main organ and ESR application to the model of pancreatic disorders. Nippon Geka Gakkaiz Asshi 2:169-173.

Nonaka A, Manabe T, and Tobe T (1991). Effect of a new synthetic ascorbic acid derivative as a free radical scavenger on the development of acute pancreatitis in mice. Gut $32: 528-532$.

Norman J, Franz M, and Riker A (1994). Rapid elevation of systemic cytokines during acute pancreatitis and their origination within the pancreas. Surg Forum 45:148-150.

Okumura N, Sakakibara A, and Hayakawa T (1982). Pancreatic endocrine function in experimental pancreatolithiasis in dogs. Am J Gastroenterol 77:392-396.

Oliver C, Waters JF, and Tolbert CL (1987). Growth of exocrine acinar cells on a reconstituted basement membrane gel. In Vitro Cell Dev Biol 23:465-473.

Petrone WF, English DK, and Wong K (1980). Free radicals and inflammation: Superoxide-dependent activation of a neutrophil chemotactic factor in plasma. Proc Nat Acad Sci USA 77:1159-1163.

Rinderknecht H (1993). Pancreatic secretory enzymes, 2nd ed. In: Go VW, DiMagno EP, Gardner JD, Lebenthal E, Reber HA, and Scheele GA, editors. The pancreas: Biology, pathobiology, and disease. New York: Raven Press, 219-253.

Sanfey H, Bulkeley GB, and Cameron JL (1985). The pathogenesis of acute pancreatitis: The source and role of oxygenderived free radicals in three different experimental models. Ann Surg 201:63-69.

Sato S, Stark HA, Martinez J, Beaven MA, Jensen RT, and Gardner JD (1989). Receptor occupation, calcium mobilization, and amylase release in pancreatic acini: Effect of CCK-JMV-180. Am J Physiol 257 (Gastrointest Liver Physiol 20):G202-G209.
Schenk H, Klein M, and Erdbrugger W (1994). Distinct effects of thioredoxin and antioxidants on the activation of transcription factors NF- $\kappa \mathrm{B}$ and AP-1. Proc Natl Acad Sci USA 91:1672-1676.

Schoenberg MH, Birk D, and Beger HG (1995a). Oxidative stress in acute and chronic pancreatitis. Am J Clin Nutr 62:1306S-1314S.

Schoenberg MH, Buchler M, and Beger HG (1988). Lipid peroxidation products in the pancreatic tissue of patients with acute pancreatitis. Br J Surg 75:1254-1262.

Schoenberg MH, Buchler M, and Gasper M (1990). The involvement of oxygen radicals in acute pancreatitis. Gut 31:1138-1143.

Schoenberg MH, Buchler M, and Pietrzyk C (1995b). Lipid peroxidation and glutathione metabolism in chronic pancreatitis. Pancreas 10:36-43.

Schreck R, Meier B, Mannel DN, Droge W, and Baeuerle PA (1992). Dithiocarbamates as potent inhibitors of nuclear factor kappa B activation in intact cells. J Exp Med 175: 1181-1194.

Scott P, Bruce C, and Schofield D (1993). Vitamin C status in patients with acute pancreatitis. Br J Surg 80:750-754.

Steinle AU, Weidenbach H, Wagner M, Adler G, and Schmid RM (1999). NF- $\kappa$ B/Rel activation in cerulein pancreatitis. Gastroenterology 116:420-430.

Thurman RG, Ley HG, and Scholz R (1972). Hepatic microsomal ethanol oxidation. Eur J Biochem 25:420-430.

Uys CJ, Bank S, and Marks IN (1973). The pathology of chronic pancreatitis in Cape Town. Digestion 9:454-468.

Willemer S, Elsasser HP, and Adler G (1992). Hormoneinduced pancreatitis. Eur Surg Res 24(Suppl 1):29-49.

Wisner J, Green D, and Ferrell L (1988). Evidence for a role of oxygen derived free radicals in the pathogenesis of ceruleininduced acute pancreatitis. Gut 29:1516-1523.

Wulczyn FG, Krappmann D, and Scheidereit C (1996). The $\mathrm{NF}-\kappa \mathrm{B} / \mathrm{Rel}$ and $\mathrm{I}_{\kappa} \mathrm{B}$ gene families: Mediators of immune response and inflammation. J Mol Med 74:749-769.

Yagi KA (1976). Simple fluorometric assay for lipoperoxide in blood plasma. Biochem Med 15:212-216.

Zar BH (1984). Biostatistical analysis, 2nd ed. Englewood Cliffs: Prentice-Hall. 